Research Article

\title{
Performance and Emission Characteristics of Pyrolysis Oil Obtained from Neem de Oiled Cake and Waste Polystyrene in a Compression Ignition Engine
}

\author{
D. Raguraman, ${ }^{1}$ Aditya Kumar, ${ }^{2}$ S. Prasanna Raj Yadav, ${ }^{3}$ Pandurang Y. Patil, ${ }^{4}$ \\ J. Samson Isaac, ${ }^{5}$ C. Sowmya Dhanalakshmi $\mathbb{D}^{6},{ }^{6}$ P. Madhu $\left(\mathbb{D},{ }^{7}\right.$ \\ and J. Isaac JoshuaRamesh Lalvani $\mathbb{1}^{8}$ \\ ${ }^{1}$ School of Mechanical Engineering, Bharath Institute of Higher Education and Research, Chennai, Tamil Nadu 600126, India \\ ${ }^{2}$ Department of Mechanical Engineering, Netaji Subhas University of Technology, Dwarka, New Delhi 110078, India \\ ${ }^{3}$ Department of Mechanical Engineering, Easwari Engineering College, Chennai, Tamil Nadu 600089, India \\ ${ }^{4}$ Department of Environmental Science, Ratnagiri Sub-Campus, University of Mumbai, Ratnagiri, Maharashtra 415639, India \\ ${ }^{5}$ Department of Biomedical Engineering, Karunya Institute of Technology and Sciences, Coimbatore, Tamil Nadu 641114, India \\ ${ }^{6}$ Department of Mechanical Engineering, SNS College of Technology, Coimbatore, Tamil Nadu 641035, India \\ ${ }^{7}$ Department of Mechanical Engineering, Karpagam College of Engineering, Coimbatore, Tamil Nadu 641032, India \\ ${ }^{8}$ Faculty of Mechanical Engineering, Arba Minch Institute of Technology, Arba Minch University, P.O. Box 21, \\ Arba Minch, Ethiopia
}

Correspondence should be addressed to J. Isaac JoshuaRamesh Lalvani; isaac.jrl@amu.edu.et

Received 3 November 2021; Accepted 19 November 2021; Published 9 December 2021

Academic Editor: Erol Yilmaz

Copyright ( 2021 D. Raguraman et al. This is an open access article distributed under the Creative Commons Attribution License, which permits unrestricted use, distribution, and reproduction in any medium, provided the original work is properly cited.

Plastic is a resilient, chemically inert, lightweight, and low-cost material. It sticks around in the environment for more than hundred years, threatening nature and spreading toxins. The current study deals with the use of waste polymeric materials and de oiled cake for the production of liquid oil and its blend on the performance and emission characteristics of diesel engine. The tests were conducted in an engine fuelled with diesel and four distinct blends such as 5\% (B5), 10\% (B10), 15\% (B15), and 20\% (B20), respectively. The liquid oil was produced by co-pyrolysis of neem de oiled cake (NDC) and waste polystyrene (WPS) in $1: 2$ blend ratio. The raw pyrolysis oil and its different blends were tested for their physical and chemical characteristics in order to find their suitability. Brake power (BP), brake thermal efficiency (BTE), brake-specific fuel consumption (BSFC), emissions of carbon monoxide (CO), hydrocarbon $(\mathrm{HC})$, and nitrogen oxide ( $\mathrm{NOx}$ ) are used to assess the performance of the engine. The experimental results reveal that BTE at all blends is lower than diesel at all loads and the BSFC increases with increasing blend ratio and falls with increasing engine load. At higher loads, the deviation of performance and emission values from baseline diesel up to B10 is very small. It is found from the results that the liquid oil derived from NDC and WPS up to $10 \%$ blend will be the promising additive for fossil fuels.

\section{Introduction}

Many countries in the world have launched zero plastic waste initiative, which seeks to boost collection of wastes and recovery of value added products and eliminate plastic contamination throughout the plastics lifecycle. The increase in the global population and need for polymeric materials in all sectors led to a rise in the gathering of waste polymer materials in the environment. Waste management policies and increased fuel cost led the researchers to find possible substitute to meet increased energy demand by replacing fossil fuels [1]. Increased air, water, and soil pollutions, change of climate, and global warming are most likely to blame for the continued degradation of the global ecosystem [2]. The burning of fossil fuels in all industrial sectors and transport vehicles are the primary source of these harmful 
pollutants. The increased thermal efficiency and outstanding drivability of the diesel engine have a propensity to use in transport sector as well as power plants [3]. By 2040, the rapid development of automobiles keeps continued fuel consumption all over the world which consumes around $25 \%$ of global energy, and it is found to increase more than 160 quadrillion BTU [4]. The global economy is also increasing based on the population at a rate of $3.4 \%$ per year and anticipated to climb from 7.5 to 9 billion. The energy need for transportation sector is predicted to increase by $30 \%$ [5]. It is also estimated that, by $2050,27 \%$ of the world's transportation fuel will be derived from biomass and waste resources [6]. Many researchers have previously conducted engine performance analysis using various biodiesel and different engine modification systems. Soudagar et al. conducted engine analysis using different blends of cottonseed oil biodiesel with various percentages of octanol additives along with multiwalled carbon nanotubes. The study showed that $20 \%$ blend of biodiesel with $5 \%, 10 \%$, and $15 \%$ octanol consumes lower fuel. The addition of nanoparticles in this experiment stabilized fuel consumption and increased the BTE of the engine [7]. Karuppan et al. conducted the experiment on homogenous charge compression ignition engine fuelled with chicken fat oil biodiesel. Based on the analysis, the engine operated with blended biodiesel offers high peak pressure and higher heat release rate than neat diesel fuel [8]. Regarding emission, Verma et al. conducted experimental investigations on diesel engine operated with roselle biodiesel-diesel blend. The blend up to $20 \%$ shows $18.89 \%$ reduction in smoke compared to diesel [9]. In order to enhance the performance of the engine, Vinukumar et al. conducted the engine experiment with the addition of coconut shell nanoparticles with diesel and biodiesel blend. Without changing any modification, the engine shows better performance with reduced NOx emission [10]. Similarly, the engine operated with various blends of mahua biodiesel and sardine fish oil biodiesel showed better performance compared to diesel fuel $[11,12]$.

Waste plastics are a form of waste that is abundant and may be utilised for generating electricity. Plastic manufacturing has increased dramatically for the past three decades, reaching more than 130 million tonnes per year [13]. Synthetic polymers such as polyethylene, polypropylene, polyvinyl chloride, and polystyrene have seen a substantial increase in use for the last twenty years. These materials are long-lasting and light-weight used for households and industrial purposes but disposing of these wastes is the serious issue by considering sustainable environment. The old and traditional plastic waste disposal method followed in many parts of the world is land filing. But it should not be disposed since these plastics are disintegrated for up to 1,000 years. As a result, a proper recycling of these wastes should be identified by various recycling processes such as mechanical, chemical, biological, and thermal recycling. Biofuels made from waste materials are garnering a lot of attention and interest because of their numerous benefits and the availability of their feedstocks. Many researchers have focused on biofuel generation by utilizing agricultural residues and waste plastics through pyrolysis, hydropyrolysis, and catalytic cracking [14]. The type employed for the study is based on the type of feedstock material, precursor, and final form of fuel. The benefits of the pyrolysis technique compared to other techniques for biofuel production have been highlighted by several studies $[15,16]$. In pyrolysis, the waste solid particles are transformed into liquid oil by applying heat up to $750^{\circ} \mathrm{C}$ with maximum liquid yield of $60-70 \%$. The bio-oil produced from biomass materials on the other hand has unstable fuel characteristics compared to mineral oil. The water content in the bio-oil is the main drawback that decreases the energy content of the fuel [17]. Co-pyrolysis process of biomass with synthetic waste polymer may be explored to enhance the stability of the produced oil. Polymers in the co-pyrolysis process act as hydrogen donors with less hydrogen containing lignocellulosic materials such as biomass. The plastic wastes are generally having higher hydrogen molecules that enhance the stability of the liquid product when pyrolyzed with biomass materials compared to thermal biomass pyrolysis [18]. From the data obtained from previous studies, this process yields high-quality liquid products due to synergetic effects [19-22] and can be utilised in internal combustion engines.

During biodiesel synthesis process, a bulk quantity $(\sim 40 \%)$ of solid waste is produced from the oil feedstocks. For example, neem seed is a potential feedstock producing neem seed oil. It is nonedible seed that contains up to $60 \%$ oil kernel and $40 \%$ neem de oiled cake (NDC) $[23,24]$. It is an industrial by-product, and it has received higher interest since it is available abundantly through many oil industries. However, the major disadvantage with this feedstock is the presence of excess oxygen. Therefore, utilization of liquid oil obtained from thermal pyrolysis of raw NDC would result in engine damage as well as the emission of $\mathrm{CO}, \mathrm{HC}$, and $\mathrm{NOx}$. By considering the above drawbacks, co-pyrolysis of NDC with waste polymeric material is selected for making highgrade liquid oil. Among all types of plastic wastes, polystyrene has attracted the attention of many researchers due to higher volatiles and recovery rate [25]. At 2016, more than 54 million $\mathrm{kg}$ of expanded polystyrene wastes were recycled into various forms. Normally, the waste recycling stations do not accept expanded waste polystyrenes due to their higher carbon footprints and higher processing charge [26]. On the other hand, it is a low-cost raw material for the production of fuels and valuable chemicals. These wastes produce less gaseous products with less insoluble organic materials, minimising the environmental effect caused by waste plastics [27]. These are the main reasons to choose waste polystyrene for oil extraction purpose. Polystyrene or waste thermocol is used as a co-feed with biomass pyrolysis yielding highquality liquid oil due to a synergistic effect [28]. For the past two decades, the researchers have hardly studied the behaviour of the various engines operated with co-pyrolysis oil as a fuel. Previously, Mohapatra et al. [4] conducted various analyses on IC engine using different blends of liquid oil derived from sugarcane bagasse and thermocol wastes. When compared to neat diesel oil, the authors found that $5 \%$ blend has improved performance and emissions characteristics. Pradhan et al. [29] studied engine performance 
analysis of diesel blended with pyrolysis oil obtained from the mixture of mahua seeds and waste thermocol, and they reported some decrement in BTE and NOx with increased blend.

The present work in this series also focuses on the assessment of performance and emission characteristics of diesel engine using co-pyrolysis oil produced from NDC and WT. The engine was investigated by using four different blends of neat diesel and co-pyrolysis oil. The primary objective is to explore the use of waste polymeric materials and de oiled cake for the production of liquid oil and its blend on diesel engine performance. There are no literatures that focused on engine studies using different biodiesel blends obtained from nonedible seed cake and waste polystyrene.

\section{Materials and Methods}

2.1. Materials. Neem de oiled cake used for this study is collected from local oil industries in Coimbatore, India. It is rich in protein, with higher nutritional value. After oil extraction, these cakes are processed for making fertilizers and sometimes they are used for cooking purpose. The waste polystyrene used for packing electronic goods was also collected from local scrap vendors. The two feed materials used for this study are complete industrial waste products. The NDC was dried in open atmosphere for more than 15 days and then oven dried at approximately $60^{\circ} \mathrm{C}$ for 12 hours. The waste polystyrene collected for this study is $95 \%$ air with high volume. In order to reduce its volume, the material was shredded and then dried at $100^{\circ} \mathrm{C}$. Figure 1 shows the photographic views of the feedstock materials used for this study.

2.2. Characterization. Various characterizations of the selected materials are done to find the suitability for pyrolysis process as displayed in Table 1 . The analysis was carried out by air dry basis. All the analyses are carried out by following ASTM standard test procedures reported in Table 1. Parr6772 bomb calorimeter is employed to find the calorific value of the feedstocks, oil, and tested fuel. After extracting co-pyrolysis oil, the various properties such as density, kinematic viscosity, flash point, fire point, cetane number, carbon residue, and calorific value are analysed.

2.3. Pyrolyzer Setup. The co-pyrolysis experiments were conducted to extract pyrolysis oil by utilizing lab-scale fixed bed reactor. The reactor (diameter: $100 \mathrm{~mm}$, length: $150 \mathrm{~mm}$ ) holds around $50 \mathrm{~g}$ of feed materials blended in the ratio of 1 : 2 (NDC: WPS) per run. The experiments were repeated till adequate amount of oil was extracted for this study under the same operating conditions. Required amount of heat is applied to the reactor via $2000 \mathrm{~W}$ electrical heater and controlled by autotransformer which controls the heat input rate. The reactor is maintained at $550^{\circ} \mathrm{C}$ which is measured by two $\mathrm{K}$ type thermocouples positioned at two different points. The evolved gases passed through a condenser to convert condensable volatiles into liquid oil. The temperature of the water in condenser circuit is maintained less than $5^{\circ} \mathrm{C}$.

2.4. Engine Setup. The engine setup used for this study is Kirloskar make TV1 single-cylinder, four-stroke compression ignition type. The engine is attached with various pieces of equipment to measure crank angle, pressure, airflow, temperature, load, and fuel flow. The setup is also configured with a manometer, fuel flow measurement system, air flow measurement system, and process indicator. The engine is generating a rated output power of $5.20 \mathrm{~kW}$. The swept volume of the engine is found as $661.45 \mathrm{cc}$. Table 2 contains the engine's basic specifications. The gas emitted from the engine is allowed through AVL type multigas analyzer to compute the level of CO, HC, and NOx. The tests are carried out on different blends of pyrolysis oil and diesel. Figure 2 shows the block diagram of the engine test-rig.

2.5. Characterization of Co-Pyrolysis Oil and Blends. The pyrolysis and its blends with neat diesel, namely, B5, B10, $\mathrm{B} 15$, and B20, are analysed for its basic fuel properties such as viscosity, density flash point, fire point, cetane number, carbon residue, and calorific value, and their values are exhibited in Table 3. All the properties are measured in accordance with ASTM standards. FTIR spectroscopy is also employed to examine the functional groups present in the co-pyrolysis oil. The FTIR spectrum data was taken in the range $400-4000 \mathrm{~cm}^{-1}$ with $4 \mathrm{~cm}^{-1}$ resolution.

\section{Results and Discussion}

3.1. Pyrolysis and Its Product Characterization. During copyrolysis experiments, a maximum of $73.4 \mathrm{wt} \%$ of pyrolysis oil yield was obtained using feed ratio of $1: 2$ (NDC: WPS) at $550^{\circ} \mathrm{C}$ reactor temperature. Table 4 describes the basic properties of co-pyrolysis oil and its blends along with diesel. The basic properties of diesel were somewhat changed when it was blended with co-pyrolysis oil. During blends, the density and kinematic viscosity are observed in increased trends. The flash and fire points of the blended fuels are increased up to B10; after that, the values are decreased till B20. The cetane number of the raw co-pyrolysis oil is very low compared to diesel, and the reductions in cetane number with respect to higher blends are ascribed to the presence of polystyrene contents [30]. The calorific value of the blended fuel was directly impacted by the presence of oxygen in the blend [31].

3.2. FTIR Analysis of Co-Pyrolysis Oil. The FTIR spectrum of the co-pyrolysis oil is shown in Figure 3. The oil was found with the combination of various aliphatic hydrocarbons with the absorption peaks of $3100.66 \mathrm{~cm}^{-1}$ and $2833.55 \mathrm{~cm}^{-1}$. The oxygenated compounds in the oil were shown by the appearance of $\mathrm{C}=\mathrm{O}$ stretching vibration at $1738.13 \mathrm{~cm}^{-1}$, also showing the existence of carbonyl group. The alcohols and esters compound in the oil was detected by $\mathrm{O}-\mathrm{H}$ stretching vibrations at $3619.9 \mathrm{~cm}^{-1}$ and $\mathrm{C}-\mathrm{O}$ stretching vibrations at 


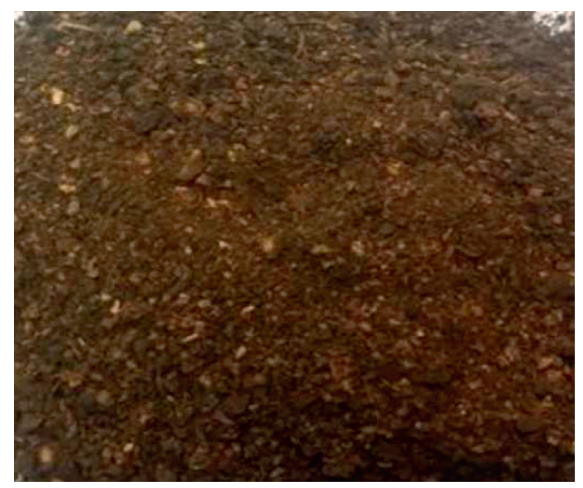

(a)

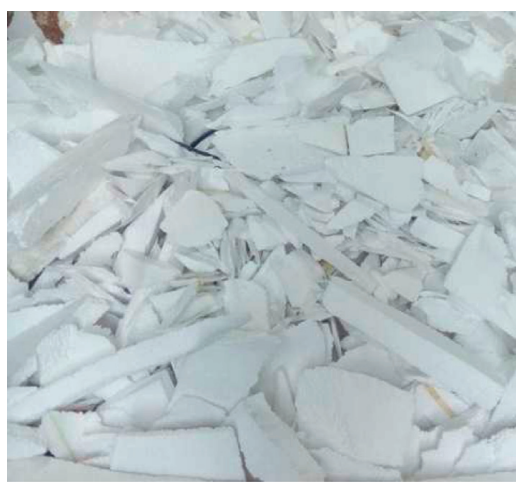

(b)

Figure 1: Feedstock material for co-pyrolysis oil. (a) Neem de oiled cake. (b) Waste polystyrene.

TABle 1: Feedstock characteristics.

\begin{tabular}{lccccccccc}
\hline Material & $\begin{array}{c}\text { Volatile } \\
\text { matter }\end{array}$ & $\begin{array}{c}\text { Fixed } \\
\text { carbon }\end{array}$ & Moisture & Ash & Carbon & Hydrogen & Nitrogen & $\begin{array}{c}\text { Sulphur } \\
\text { Oxygen }\end{array}$ & $\begin{array}{c}\text { Calorific } \\
\text { value }\end{array}$ \\
\hline NDC & 78.25 & 8.91 & 7.52 & 5.32 & 51.62 & 5.27 & 3.1 & 0.31 & 39.7 \\
WPS & 98.18 & 0.49 & 0.24 & 1.09 & 89.2 & 8.82 & 0.01 & - & 1.97 \\
Standard & ASTM D3175 & $\begin{array}{c}\text { By } \\
\text { difference }\end{array}$ & $\begin{array}{c}\text { ASTM } \\
\text { D3173 }\end{array}$ & $\begin{array}{c}\text { ASTM } \\
\text { D3174 }\end{array}$ & & ASTM D5373 & By & ASTM D445 \\
\hline
\end{tabular}

TABle 2: Engine setup and specification.

\begin{tabular}{lc}
\hline Make and model & Kirloskar TV 1 \\
\hline Type & Four strokes, compression ignition, water \\
cooled & $17.5: 1$ \\
Compression & Single \\
ratio & $5.2 \mathrm{~kW}$ \\
No. of cylinders & $661 \mathrm{cc}$ \\
Rated power & $87.5 \mathrm{~mm}$ \\
Engine capacity & $1500 \mathrm{rpm}$ \\
Bore & $110 \mathrm{~mm}$ \\
Rated speed & $210 \mathrm{bar}$ \\
Stroke & Eddy current \\
Injection pressure & $23^{\circ} \mathrm{bTDC}$ \\
Dynamometer & \\
Start of injection &
\end{tabular}

$1177.37 \mathrm{~cm}^{-1}$. The $\mathrm{N}-\mathrm{H}$ bend obtained at 1490.83 shows the presence of amides in the liquid oil. The $\mathrm{C}=\mathrm{C}$ stretching at $1430.27 \mathrm{~cm}^{-1}$ indicates the presence of aromatic compounds in the co-pyrolysis oil. The $\mathrm{C}-\mathrm{H}$ bending vibrations at $752 \mathrm{~cm}^{-1}$ showed an indication of aromatic hydrocarbons or arenes. The $\mathrm{C}-\mathrm{H}$ bend that appeared at 674.31 shows the presence of aromatic compounds in the oil sample. The presence of strong aromatic compounds also occurred in the previous study $[32,33]$.

\subsection{Engine Performance Analysis}

3.3.1. Brake Power. Figure 4 depicts the variance in braking power with respect to engine load. The brake power of an IC engine is generally defined as the power available at the crankshaft. With increasing engine loads, the value of brake power for all tested fuels exhibited in increased trend. The brake power of the engine at full load conditions is 3.52, 3.45, $3.41,3.3$, and $3.18 \mathrm{~kW}$ for diesel, B5, B10, B15, and B20, respectively. Comparing with diesel, the result showed $1.99 \%$ and $3.13 \%$ decrement in brake power while the engine is operated at B5 and B10. For B15 and B20, the decrement in brake power was recorded as $6.25 \%$ and $9.66 \%$, respectively, compared to diesel. At higher load operating condition beyond B10, a considerable loss in brake power was recorded. The higher decrements in brake power beyond $\mathrm{B} 10$ are due to inferior combustion properties of the fuel. The higher viscosity, presence of oxygen, and reduced calorific value decreased the engine brake power in all loads [34]. The same trends also obtained on CI engine were analysed by Pradhan et al. [29].

3.3.2. Brake-Specific Fuel Consumption. BSFC is basically defined by the ratio of the amount of fuel spent in $\mathrm{kg}$ to the engine's unit power output in $\mathrm{kWh}$ at the same engine load. It is the indicator used for the measurement of performance of any fuel. The values of BSFC are always expected to be low to the modified test fuels. Figure 5 shows the effect in BSFC based on different loads. The blended fuels achieved higher specific fuel consumptions for engine load than diesel oil due to its lower energy content in contrast with diesel. So to provide the same power output, the blended fuel requires injecting more fuel than diesel. As the volume proportion of co-pyrolysis oil to diesel oil increased, the value of BSFC increased for all loads. The higher viscosity of the blended fuels resulted in bigger fuel droplets due to poor atomization, penetration, and air-fuel mixing. Hence, it deteriorates 


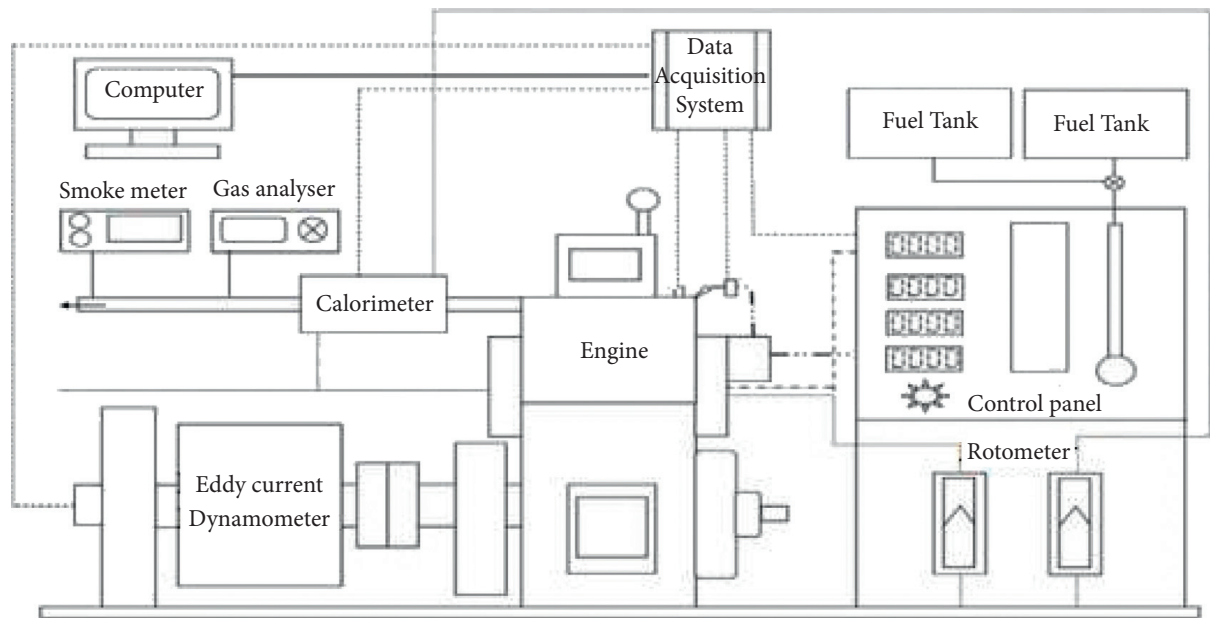

Figure 2: Block diagram of engine testing setup.

TABle 3: Blend type with diesel.

\begin{tabular}{lc}
\hline Co-pyrolysis oil + diesel percentage & Blend name \\
\hline $0 \%+100 \%$ & $\mathrm{D}$ \\
$5 \%+95 \%$ & $\mathrm{~B} 5$ \\
$10 \%+90 \%$ & $\mathrm{~B} 10$ \\
$15 \%+85 \%$ & $\mathrm{~B} 15$ \\
$20 \%+80 \%$ & $\mathrm{~B} 20$ \\
\hline
\end{tabular}

the burning and consumed higher fuel for specific output power [35]. The value of BSFC goes to its minimum value for all tested fuels as increased load might be due to the increased in-cylinder temperature. At elevated load conditions, the fuels can enter at proper condition to ignite to produce improved combustion efficiency. The similar pattern of output was also obtained from the previous researchers [36, 37]. In comparison to diesel fuel, the increment on the BSFC value is calculated to 3.85, 7.69, 19.23 , and $26.92 \%$ for B5, B10, B15, and B20, respectively.

3.3.3. Brake Thermal Efficiency. BTE is an important measure that demonstrates how the chemical energy of the fuel can be transformed efficiently into mechanical energy [38]. For any modified test fuel, the BTE is expected to be high by the researchers. Accordingly, Figure 6 portrayed the variation in BTE at different loads. The higher BTE value was recorded with baseline diesel fuel for all loads, while the lowest BTE value was recorded for B20 test fuel. The values of BTE at $100 \%$ load are $31.76,31.21,30.11,27.45$, and $25.03 \%$ for diesel, B5, B10, B15, and B20, respectively. A slight variation in BTE was recorded up to B10 blends. For $\mathrm{B} 5$ and $\mathrm{B} 10$, the result showed $1.73 \%$ and $5.2 \%$ decrement in $\mathrm{BTE}$, whereas for B15 and B20 the values have changed to $13.57 \%$ and $21.19 \%$, respectively. The higher variation in $\mathrm{BTE}$ for B15 and B20 blends is consistent with the previous literature, since the higher blends with higher heat loss have higher fuel consumption [39]. The blend's poor combustion character produced low BTE due to its lower volatility, lower calorific value, and increased viscosity. An improper burning characteristic due to incomplete air-fuel is also the reason for reduced BTE.

\subsection{Emission Characteristics}

3.4.1. CO Emission. Emission of $\mathrm{CO}$ is the effect of an incomplete combustion that begins to increase when the fuel cannot be oxidised or is oxidised insufficiently. Figure 7 shows the CO concentrations of diesel and blended fuels with respect to engine load. At lower loads, the $\mathrm{CO}$ emission value of blended fuels is closer to baseline diesel oil. For example, at $20 \%$ load, the $\mathrm{CO}$ emissions of diesel, B,5 and $\mathrm{B} 10$ are equal to $0.06 \%$, whereas the values for $\mathrm{B} 15$ and $\mathrm{B} 20$ are $0.07 \%$ [ 40 ]. For a rated load of $40 \%, 60 \%, 80 \%$, and $100 \%$, the emission values observed at B5 and B10 blends were the same, and they are closer to neat diesel. At full load, the values were increased as the volumetric blending ratio of copyrolysis oil was increased. The increase in $\mathrm{CO}$ was less for B5 and B10; however, these values are for B15 and B20. This is due to the inefficient combustion, low volatility, and poor fuel-air mixture caused by higher viscosity [41] and may be endorsed to the presence of various chemical elements in the co-pyrolysis oil [29]. The low cetane number of the fuel causes the combustion to deteriorate with higher $\mathrm{CO}$ emissions, as seen by the decreased in-cylinder peak pressure. However, engine is operated with low to medium blended fuel at medium load, the level of increase in CO emissions is moderate and has no practical implications.

3.4.2. HC Emission. Figure 8 illustrates the emission of HC concentrations based on engine load. Reduced loads resulted in lower HC emissions, whereas higher loads resulted in higher HC concentrations. The higher level of HC emissions is source $d$ from incomplete combustion of fuel-air mixture. At $100 \%$ load, conditions for baseline diesel fuel HC emission varied from $23 \mathrm{ppm}$ at $20 \%$ load and $29 \mathrm{ppm}$. For $\mathrm{B} 5$ and B10, it changed from $25 \mathrm{ppm}$ and $26 \mathrm{ppm}$ to $30 \mathrm{ppm}$ and $31 \mathrm{ppm}$ at $20 \%$ load to $100 \%$ load, respectively. In this study, increased blend increases the emission of $\mathrm{HC}$. The increase in $\mathrm{HC}$ emission was less in case of $\mathrm{B} 5$ and $\mathrm{B} 10$, 
Table 4: Properties of the fuel.

\begin{tabular}{|c|c|c|c|c|c|c|}
\hline Items & Co-pyrolysis oil & B5 & $\mathrm{B} 10$ & $\mathrm{~B} 15$ & $\mathrm{~B} 20$ & Diesel \\
\hline Density $\left(\mathrm{kg} / \mathrm{m}^{3}\right)$ & 1005 & 875 & 895 & 910 & 925 & 850 \\
\hline Kinematic viscosity $(\mathrm{cSt})$ & 4.28 & 3.95 & 4.12 & 4.15 & 4.20 & 3.9 \\
\hline Flash point $\left({ }^{\circ} \mathrm{C}\right)$ & 72 & 52 & 61 & 58 & 56 & 57 \\
\hline Fire point $\left({ }^{\circ} \mathrm{C}\right)$ & 75 & 61 & 73 & 68 & 65 & 67 \\
\hline Cetane number & 24 & 40 & 38 & 35 & 33 & 50 \\
\hline Carbon residue & 1.3 & 0.4 & 0.7 & 0.9 & 1.0 & 0.1 \\
\hline Calorific value in $\mathrm{MJ} / \mathrm{kg}$ & 40.3 & 42.76 & 42.62 & 42.10 & 41.7 & 43.60 \\
\hline \multicolumn{7}{|l|}{ Elemental analysis in wt $\%$} \\
\hline $\mathrm{C}$ & 80.2 & - & - & - & - & 86.5 \\
\hline $\mathrm{H}$ & 9.5 & - & - & - & - & 13.2 \\
\hline $\mathrm{N}$ & 0.34 & - & - & - & - & 0.02 \\
\hline$S$ & 0.01 & - & - & - & - & 0.24 \\
\hline $\mathrm{O}^{\mathrm{a}}$ & 9.95 & - & - & - & - & - \\
\hline $\mathrm{H} / \mathrm{C}$ molar ratio & 1.411 & - & - & - & - & - \\
\hline $\mathrm{O} / \mathrm{C}$ molar ratio & 0.093 & - & - & - & - & - \\
\hline Empirical formula & $\mathrm{CH}_{1.41} \mathrm{~N}_{0.003} \mathrm{O}_{0.093}$ & - & - & - & - & - \\
\hline
\end{tabular}

${ }^{a}$ Percentage of oxygen $=100 \%-(\mathrm{C} \%+\mathrm{H} \%+\mathrm{N} \%+\mathrm{S} \%)$.

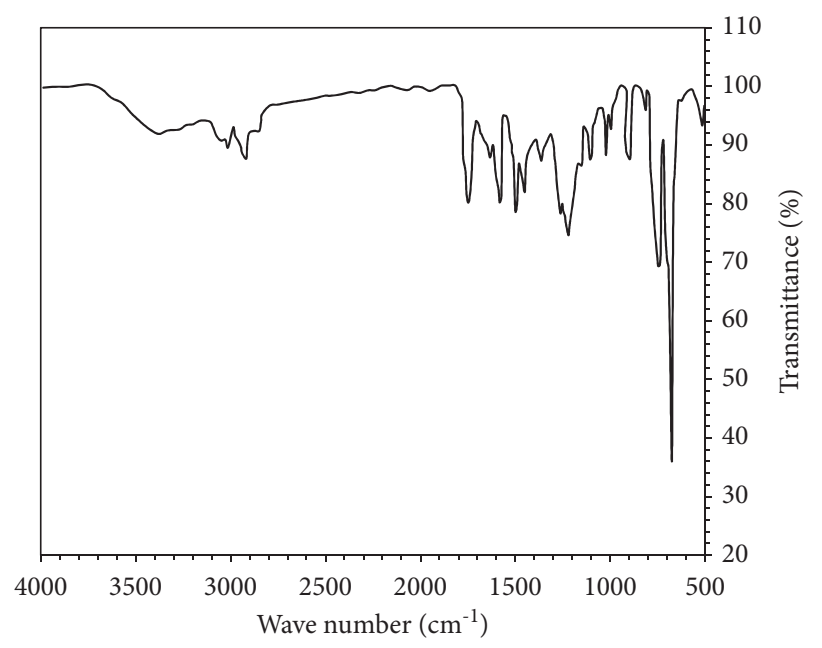

FigURE 3: FTIR spectrum of co-pyrolysis oil.

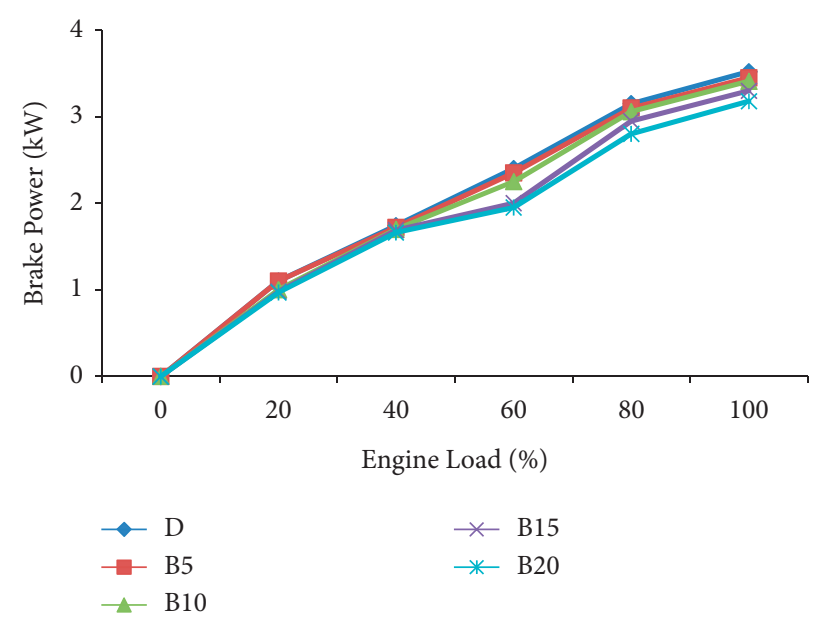

FIGURE 4: Variation of brake power with load. 


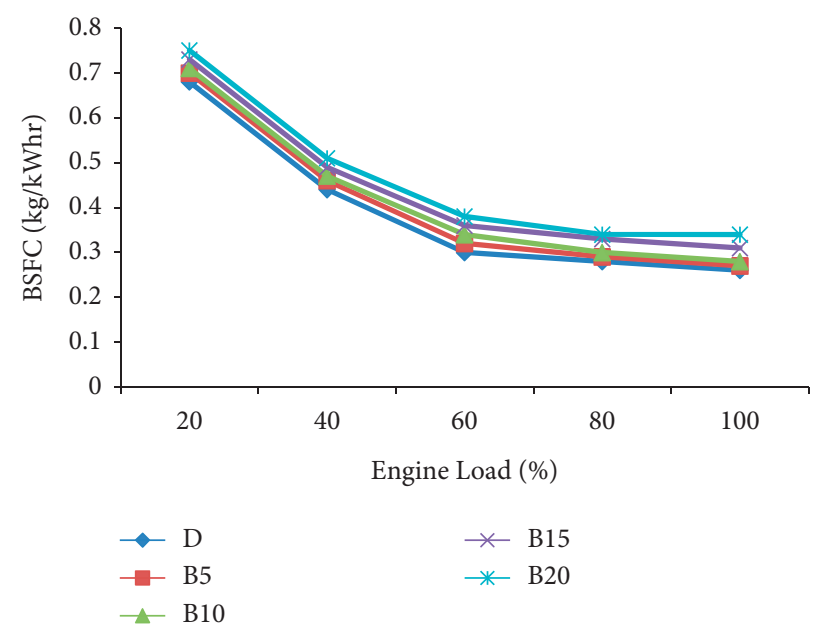

FIGURE 5: Variation of BSFC with load.

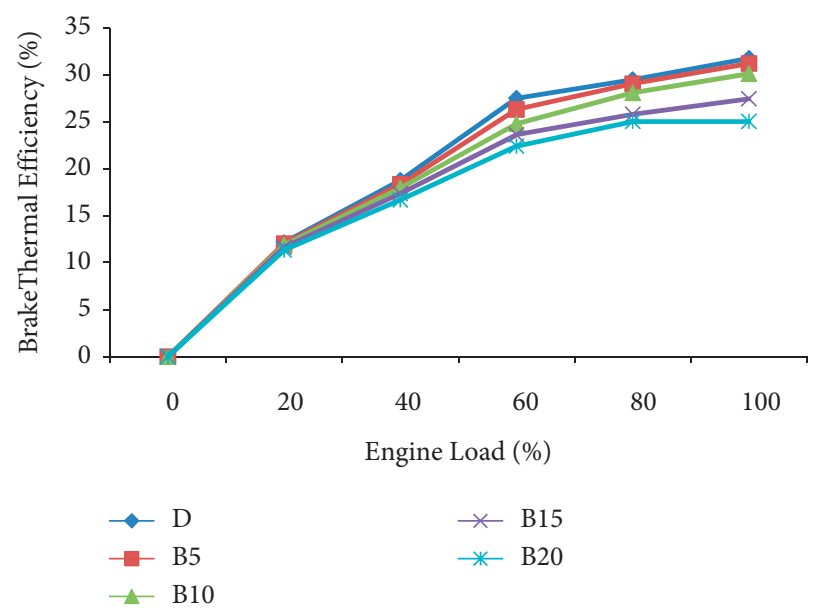

FIgURE 6: Variation of BTE with load.

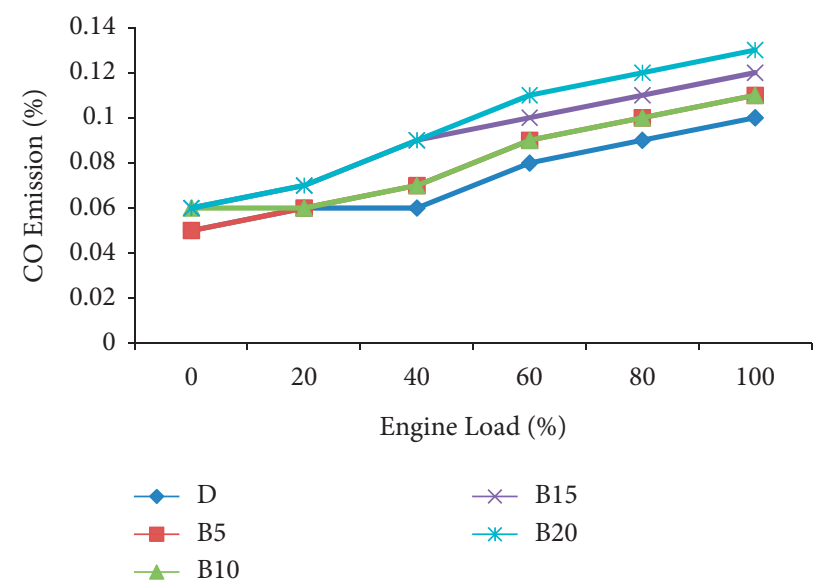

Figure 7: Variation of CO emissions with load.

though the values are more for B15 and B20. At 100\% load, the emission of $\mathrm{HC}$ for $\mathrm{B} 15$ and $\mathrm{B} 20$ is recorded as $34 \mathrm{ppm}$ and $36 \mathrm{ppm}$, respectively. In comparison to diesel fuel, the increment on the $\mathrm{HC}$ value is calculated to $3.45,6.9,17.24$, and $24.14 \%$ for $\mathrm{B} 5, \mathrm{~B} 10, \mathrm{~B} 15$, and $\mathrm{B} 20$, respectively. The increased $\mathrm{HC}$ values for increased blends are caused by the 


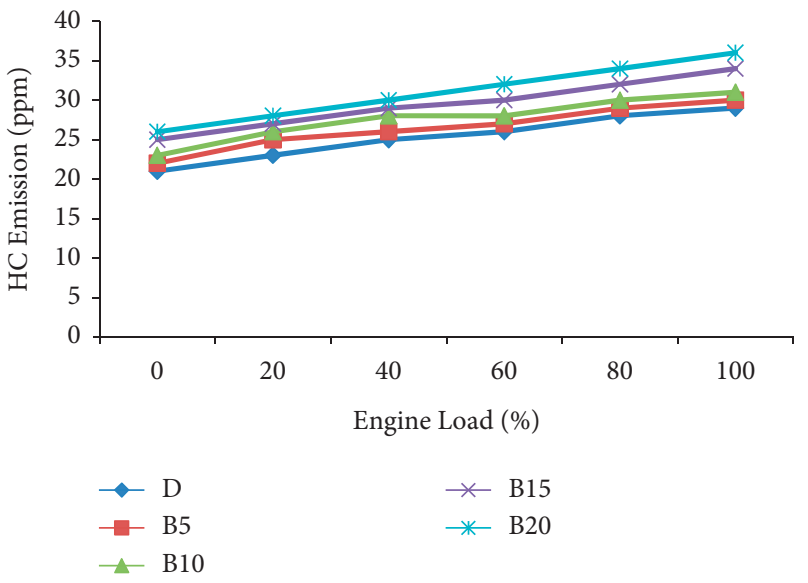

FIgURE 8: Variation of HC emissions with load.

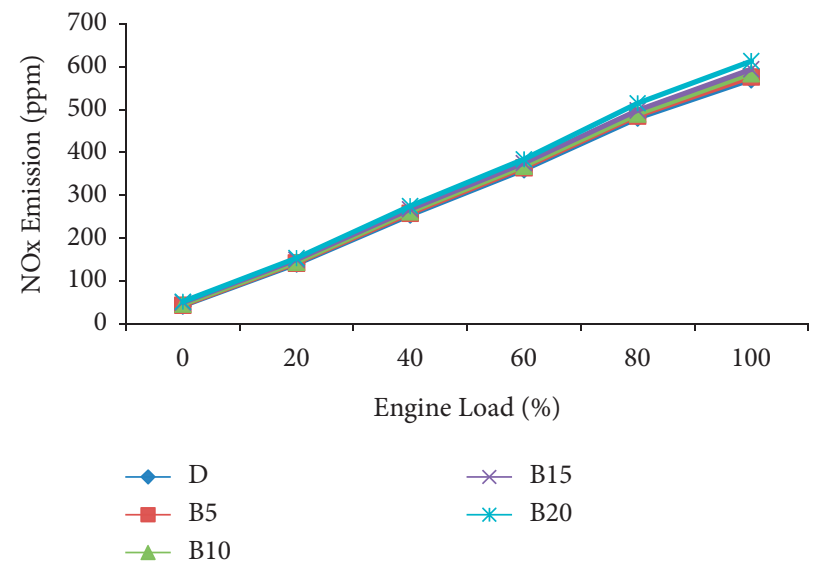

FIGURE 9: Variations of NOx emissions with load.

poor atomization, air-fuel mixing, and vaporization. The lower cetane number of the fuel causes longer ignition delay, increasing the impinging of fuel spray [42]. The presence of aromatic hydrocarbons in co-pyrolysis oil also enhanced the emission of HC since it is not breaking during combustion [43].

3.4.3. NOx Emission. NOx is another one important emission parameter which is formed inside the combustion chamber by the combination of nitrogen and oxygen. It is closely related to engine load since the formation is temperature dependent [44]. Figure 9 depicts the generation of NOx for various tested fuels. For diesel, NOx emission values are varied from $140 \mathrm{ppm}$ at $20 \%$ load and $570 \mathrm{ppm}$ at $100 \%$ load. For B5 and B10, the NOx emissions are varied from 142 to $144 \mathrm{ppm}$ at $20 \%$ load and 576 to $584 \mathrm{ppm}$ at $100 \%$ load. In general, more pyrolysis oil blends with diesel resulted in higher NOx emissions. The generation of NOx is often aided by higher oxygen levels in the combustion chamber [45]. Similarly, co-pyrolysis oil produced from waste polystyrene and neem de oiled cake has certain oxygenated hydrocarbons, promoting the formation of $\mathrm{NOx}$ during combustion.

\section{Conclusion}

Co-pyrolysis oil from neem de oiled cake and waste polystyrene with the blend ratio of $1: 2$ were produced at the temperature of $550^{\circ} \mathrm{C}$ and blended with diesel to make different blends such as B5, B10, B15, and B20. The experimental results showed that $\mathrm{B} 5$ and $\mathrm{B} 10$ have quite related output properties like diesel. The BTE for all blended fuels is lower than diesel at all load conditions due to reduced calorific value. The value of BSFC increases with higher blend and decreased with increased load. The value of $\mathrm{CO}$, $\mathrm{HC}$, and NOx emissions increased as the amount of copyrolysis oil in the blend increases. Up to $10 \%$ blend, the decrement in engine performance and increment in engine emission are very minimal. From the results, it can be understood that the liquid oil derived from neem de oiled cake and waste polystyrene can be used as a promising 
additive for fossil fuels. Further improvement can be possible by adding nanofuel additives, engine modification such as thermal barrier coating, and exhaust gas recirculation.

\section{Nomenclature}

$\begin{array}{ll}\text { NDC: } & \text { Neem de oiled cake } \\ \text { WPS: } & \text { Waste polystyrene } \\ \text { BTU: } & \text { British thermal unit } \\ \text { IC: } & \text { Internal combustion } \\ \text { CI: } & \text { Compression ignition } \\ \text { BP: } & \text { Brake power } \\ \text { BTE: } & \text { Brake thermal efficiency } \\ \text { BSFC: } & \text { Brake-specific fuel consumption } \\ \text { CO: } & \text { Carbon monoxide } \\ \text { HC: } & \text { Unburnt hydrocarbon } \\ \text { NOx: } & \text { Oxides of nitrogen } \\ \text { ASTM: } & \text { American Society for Testing and Materials } \\ \text { C: } & \text { Carbon } \\ \text { H: } & \text { Hydrogen } \\ \text { N: } & \text { Nitrogen } \\ \text { S: } & \text { Sulphur } \\ \text { FTIR: } & \text { Fourier transform infrared spectroscopy. }\end{array}$

\section{Data Availability}

The data used to support the findings of this study are included within the article.

\section{Conflicts of Interest}

The authors declare that there are no conflicts of interest regarding the publication of this article.

\section{References}

[1] A. Demirbas, "Potential applications of renewable energy sources, biomass combustion problems in boiler power systems and combustion related environmental issues," Progress in Energy and Combustion Science, vol. 31, no. 2, pp. 171-192, 2005.

[2] R. R. Appannagari, "Environmental pollution causes and consequences: a study," North Asian International Research Journal of Social Science and Humanities, vol. 3, no. 8, pp. 151-161, 2017.

[3] S. Curran, V. Prikhodko, K. Cho et al., "In-cylinder fuel blending of gasoline/diesel for improved efficiency and lowest possible emissions on a multi-cylinder light-duty diesel engine," SAE International, Warrendale, PA, USA, (No. 201001-2206). SAE Technical Paper, 2010.

[4] S. S. Mohapatra, M. K. Rath, R. K. Singh, and S. Murugan, "Performance and emission analysis of co-pyrolytic oil obtained from sugarcane bagasse and polystyrene in a CI engine," Fuel, vol. 298, Article ID 120813, 2021.

[5] M. Mohsin, Q. Abbas, J. Zhang, M. Ikram, and N. Iqbal, "Integrated effect of energy consumption, economic development, and population growth on $\mathrm{CO} 2$ based environmental degradation: a case of transport sector," Environmental Science and Pollution Research, vol. 26, no. 32, Article ID 32824, 2019.

[6] M. Sharifzadeh, M. Sadeqzadeh, M. Guo et al., "The multiscale challenges of biomass fast pyrolysis and bio-oil upgrading: review of the state of art and future research directions," Progress in Energy and Combustion Science, vol. 71, pp. 1-80, 2019.

[7] M. E. M. Soudagar, A. Afzal, M. R. Safaei et al., "Investigation on the effect of cottonseed oil blended with different percentages of octanol and suspended MWCNT nanoparticles on diesel engine characteristic," Journal of Thermal Analysis and Calorimetry, pp. 1-18, 2020.

[8] D. Karuppan, A. M. Manokar, P. Vijayabalan et al., "Experimental investigation on pressure and heat release HCCI engine operated with chicken fat oil/diesel-gasoline blends," Materials Today: Proceedings, vol. 32, pp. 437-444, 2020.

[9] T. N. Verma, U. Rajak, A. Dasore et al., "Experimental and empirical investigation of a CI engine fuelled with blends of diesel and roselle biodiesel," Scientific Reports, vol. 11, no. 1, pp. 1-23, 2021.

[10] K. Vinukumar, A. Azhagurajan, S. C. Vettivel, N. Vedaraman, and A. H. Lenin, "Biodiesel with nano additives from coconut shell for decreasing emissions in diesel engines," Fuel, vol. 222, pp. 180-184, 2018.

[11] A. H. Lenin, R. Ravi, and K. Thyagarajan, "Performance characteristics of a diesel engine using mahua biodiesel as alternate fuel," Iranica Journal of Energy and Environment, vol. 4, no. 2, pp. 136-141, 2013.

[12] R. K. Kamaraj, G. R. Jinu, A. F. Panimayam, and H. L. Allasi, "Performance and exhaust emission optimization of a dual fuel engine by response surface methodology," Energies, vol. 11, no. 12, Article ID 3508, 2018.

[13] P. H. Vu, O. Nishida, H. Fujita, W. Harano, N. Toyoshima, and M. Iteya, "Reduction of NOx and PM from diesel engines by WPD emulsified fuel," SAE International, Warrendale, A, USA, (No. 2001-01-0152). SAE Technical Paper, 2001.

[14] A. Dewangan, D. Pradhan, and R. K. Singh, "Co-pyrolysis of sugarcane bagasse and low-density polyethylene: influence of plastic on pyrolysis product yield," Fuel, vol. 185, pp. 508-516, 2016.

[15] Z. Wang, K. G. Burra, T. Lei, and A. K. Gupta, "Co-pyrolysis of waste plastic and solid biomass for synergistic production of biofuels and chemicals-a review," Progress in Energy and Combustion Science, vol. 84, Article ID 100899, 2021.

[16] R. K. Singh and K. P. Shadangi, "Liquid fuel from castor seeds by pyrolysis," Fuel, vol. 90, no. 7, pp. 2538-2544, 2011.

[17] E. Önal, B. B. Uzun, and A. E. Pütün, "Bio-oil production via co-pyrolysis of almond shell as biomass and high density polyethylene," Energy Conversion and Management, vol. 78, pp. 704-710, 2014.

[18] H. J. Park, H. S. Heo, K. S. Yoo et al., “Thermal degradation of plywood with block polypropylene in TG and batch reactor system," Journal of Industrial and Engineering Chemistry, vol. 17, no. 3, pp. 549-553, 2011.

[19] F. Abnisa, W. W. Daud, S. Ramalingam, M. N. B. M. Azemi, and J. N. Sahu, "Co-pyrolysis of palm shell and polystyrene waste mixtures to synthesis liquid fuel," Fuel, vol. 108, pp. 311-318, 2013.

[20] V. I. Sharypov, N. G. Beregovtsova, B. N. Kuznetsov et al., "Co-pyrolysis of wood biomass and synthetic polymers mixtures: part IV: catalytic pyrolysis of pine wood and polyolefinic polymers mixtures in hydrogen atmosphere," Journal of Analytical and Applied Pyrolysis, vol. 76, no. 1-2, pp. 265-270, 2006.

[21] N. Marin, S. Collura, V. I. Sharypov et al., "Copyrolysis of wood biomass and synthetic polymers mixtures. part II: characterisation of the liquid phases," Journal of Analytical and Applied Pyrolysis, vol. 65, no. 1, pp. 41-55, 2002. 
[22] S. Papari, H. Bamdad, and F. Berruti, "Pyrolytic conversion of plastic waste to value-added products and fuels: a review," Materials, vol. 14, no. 10, p. 2586, 2021.

[23] J. N. Nair, A. K. Kaviti, and A. K. Daram, "Analysis of performance and emission on compression ignition engine fuelled with blends of neem biodiesel," Egyptian Journal of Petroleum, vol. 26, no. 4, pp. 927-931, 2017.

[24] S Rathinam, J.B Sajin, G Subbiah, A Rajeev, and S PrakashS, "Assessment of the emission characteristics of the diesel engine with nano-particle in neem biodiesel," Energy Sources, Part A: Recovery, Utilization, and Environmental Effects, vol. 42, no. 21, pp. 2623-2631, 2020.

[25] K. B. Park, Y. S. Jeong, B. Guzelciftci, and J. S. Kim, "Twostage pyrolysis of polystyrene: pyrolysis oil as a source of fuels or benzene, toluene, ethylbenzene, and xylenes," Applied Energy, vol. 259, Article ID 114240, 2020.

[26] R. R. N. Bhattacharya, K. Chandrasekhar, P. Roy, M. V. Deepthi, and A. Khan, "Challenges and opportunities: plastic waste management in India," The Energy and Resources Institute, vol. 24, 2018.

[27] B. B. Uzoejinwa, X. He, S. Wang, A. E. F. Abomohra, Y. Hu, and Q. Wang, "Co-pyrolysis of biomass and waste plastics as a thermochemical conversion technology for high-grade biofuel production: recent progress and future directions elsewhere worldwide," Energy Conversion and Management, vol. 163, pp. 468-492, 2018.

[28] R. Prakash, R. K. Singh, and S. Murugan, "Experimental investigation on a diesel engine fueled with bio-oil derived from waste wood-biodiesel emulsions," Energy, vol. 55, pp. 610-618, 2013.

[29] D. Pradhan, V. Volli, R. K. Singh, and S. Murgun, "Co-pyrolysis behavior, engine performance characteristics, and thermodynamics of liquid fuels from mahua seeds and waste thermocol: a comprehensive study," Chemical Engineering Journal, vol. 393, Article ID 124749, 2020.

[30] P. R. Churkunti, J. Mattson, C. Depcik, and G. Devlin, "Combustion analysis of pyrolysis end of life plastic fuel blended with ultra low sulfur diesel," Fuel Processing Technology, vol. 142, pp. 212-218, 2016.

[31] Q. Van Nguyen, Y. S. Choi, S. K. Choi, Y. W. Jeong, and Y.S. Kwon, "Improvement of bio-crude oil properties via copyrolysis of pine sawdust and waste polystyrene foam," Journal of Environmental Management, vol. 237, pp. 24-29, 2019.

[32] G. Özsin and A. E. Pütün, "A comparative study on co-pyrolysis of lignocellulosic biomass with polyethylene terephthalate, polystyrene, and polyvinyl chloride: synergistic effects and product characteristics," Journal of Cleaner Production, vol. 205, no. 20, pp. 1127-1138, 2018.

[33] F. Abnisa, W. W. Daud, and J. N. Sahu, "Optimization and characterization studies on bio-oil production from palm shell by pyrolysis using response surface methodology," Biomass and Bioenergy, vol. 35, no. 8, pp. 3604-3616, 2011.

[34] L. Tarabet, K. Loubar, M. S. Lounici, S. Hanchi, and M. Tazerout, "Experimental evaluation of performance and emissions of DI diesel engine fuelled with eucalyptus biodiesel," in Proceedings of the Internal Combustion Engines: Performance, Fuel Economy and Emissions, pp. 167-176, 2011.

[35] G. Chen, C. Liu, W. Ma et al., "Co-pyrolysis of corn cob and waste cooking oil in a fixed bed," Bioresource Technology, vol. 166, pp. 500-507, 2014.

[36] M. Karagöz, Ü. Ağbulut, and S. Sarıdemir, "Waste to energy: production of waste tire pyrolysis oil and comprehensive analysis of its usability in diesel engines," Fuel, vol. 275, Article ID 117844, 2020.

[37] Ü. Ağbulut, A. E. Gürel, and S. Sarıdemir, "Experimental investigation and prediction of performance and emission responses of a CI engine fuelled with different metal-oxide based nanoparticles-diesel blends using different machine learning algorithms," Energy, vol. 215, Article ID 119076, 2021.

[38] N. Phetyim and S. Pivsa-Art, "Prototype co-Pyrolysis of used lubricant oil and mixed plastic waste to produce a diesel-like fuel," Energies, vol. 11, no. 11, p. 2973, 2018.

[39] S. Lee, L. Chen, K. Yoshida, and K. Yoshikawa, "Application of waste biomass pyrolysis oil in a direct injection diesel engine: for a small scale non-grid electrification," Journal of Energy and Power Engineering, vol. 9, pp. 929-943, 2015.

[40] A. Dhar and A. K. Agarwal, "Performance, emissions and combustion characteristics of Karanja biodiesel in a transportation engine," Fuel, vol. 119, pp. 70-80, 2014.

[41] T. Ito, Y. Sakurai, Y. Kakuta, M. Sugano, and K. Hirano, "Biodiesel production from waste animal fats using pyrolysis method," Fuel Processing Technology, vol. 94, no. 1, pp. 47-52, 2012.

[42] M. S. Radwan, M. A. Ismail, S. M. S. Elfeky, and O. S. M. AbuElyazeed, "Jojoba methyl ester as a diesel fuel substitute: preparation and characterization," Applied Thermal Engineering, vol. 27, no. 2-3, pp. 314-322, 2007.

[43] Y. Kidoguchi, C. Yang, R. Kato, and K. Miwa, "Effects of fuel cetane number and aromatics on combustion process and emissions of a direct-injection diesel engine," JSAE Review, vol. 21, no. 4, pp. 469-475, 2000.

[44] E. Buyukkaya and M. Cerit, "Experimental study of NOx emissions and injection timing of a low heat rejection diesel engine," International Journal of thermal Sciences, vol. 47, no. 8, pp. 1096-1106, 2008.

[45] P. Senthilkumar and G. Sankaranarayanan, "Effect of Jatropha methyl ester on waste plastic oil fueled DI diesel engine," Journal of the Energy Institute, vol. 89, no. 4, pp. 504-512, 2016. 